\title{
Pre-Filled Pen Syringe Dosing Unit
}

National Cancer Institute

\section{Source}

National Cancer Institute. Pre-Filled Pen Syringe Dosing Unit. NCI Thesaurus. Code C122635.

A dosing unit equal to the amount of active ing redient(s) contained in an pre-filled pen syringe. 